\title{
EVALUATION OF LIGATION OF INTERSPHINCTERIC FISTULAS TRACT (LIFT) FOR THE TREATMENT OF TRANSSPHINCTERIC ANAL FISTULA
}

\author{
By
Abou Bakr Abd El-Kader Ateya, Mahmoud Mohamed Abu Al-Yazid and Nader Mohamed Abd El-Hameid

\author{
General Surgery Department, Faculty of Medicine (Cairo), Al-Azhar University
}

Phone: (+02) 01275388740, E-mail: bkrtantawy3@gmail.com

\begin{abstract}
Background: Fistula-in-ano consists of a primary track which passes from the internal opening in the anal canal to the external opening in the perineum. Most of the anal fistulas are originated from the infection of anal glands which are connected to the anal crypts (cryptoglandular origin). Age distribution is spread throughout adult life with maximal incidence between the third and fifth decades. Men are 2 to 5 times more likely to develop anal fistula than women.
\end{abstract}

Objective: The aim of this study was to evaluate the LIFT technique for the treatment of trans-sphincteric anal fistula.

Patients and Methods: This study included 20 patients with trans-sphincteric fistula from August 2018 till April 2020, while anal fistula due to specific disease and other types of law anal fistula have been excluded from the study. Regarding demographic data, $90 \%$ of the included patients were males and the mean age was 38 years. The median duration of symptoms was 8 months, and the median length of the fistula tracts was $7 \mathrm{~cm}$. The mean BMI of patients was 38, seven patients $(35 \%)$ were diabetic. All patients were investigated with pre-operative MRI and 3D CT fistulography.

Results: The main finding of this study was overall healing of $80 \%$ of patients, with a 6 months follow-up. There were 1 failure, and 3 recurrences between 3 and 6 months after surgery. No patients reported de novo incontinence, and all patients reported normal control. The median time for wound healing was 4 weeks.

Conclusion: LIFT Technique is quite, simple and excellent in long term control of trans-sphincteric fistula, but actually the corner stone in management of perianal fistula is the accurate diagnosis of the type of fistula, which need good preoperative imaging by both surgeon and radiologist, followed by good intraoperative assessment of the type of fistula for selection of the appropriate Technique of each type.

Keywords: Intersphincteric Fistulas Tract, Transsphincteric Anal Fistula

\section{INTRODUCTION}

A fistula-in-ano is an abnormal communication between the anal canal and the perineal skin (Baskan et al., 2014). Fistula-in-ano consists of a primary track which passes from the internal opening in the anal canal to the external opening in the perineum. In more complex cases secondary tracks may branch from the primary track (Simpson et al., 2012). Most of the anal fistulas are originated from the infection of anal glands which are connected to the anal crypts (cryptoglandular origin) (De Parades et al., 2010). Fistula- in-ano may be 
associated with trauma or specific pathologies such as malignancy, inflammatory bowel disease, tuberculosis, and perianal actinomycosis (Steele et al., 2011). Age distribution is spread throughout adult life a maximal incidence between the third and fifth decades. Anal fistulas rare in patients younger than 20 or older than 60 years (Salati and Al Kadi, 2012).

Surgery remains the only modality for the effective treatment of this condition. The main objective of the operative intervention is to heal the fistula with minimal morbidity. However, among the various alternatives for the treatment of anal fistulas, none of them is considered the technique of choice because of their recurrence rates and incontinence (Jackson et al., 2011).

\section{PATIENTS AND METHODS}

This study was carried out on 20 patients, with transsphincteric anal fistula from August 2018 to April 2020.

\section{Inclusion criteria:}

Anal fistula with trans-sphincteric track. All cases were diagnosed clinically and verified by MRI, and CT fistulgram.

\section{Exclusion criteria:}

1. Anal fistula due to specific disease.

2. Other types of anal fistula: low intersphincteric, supra-sphincteric and extra-sphincteric.

- Informed consents were obtained from all patients who were invited to participate in the research.

\section{Preoperative assessment:}

1. History taking for age, sex, BMI, DM, history of previous anal operations including previous fistula surgery, type of surgery and timing of recurrence.

2. Digital rectal examination to assess site of the external opening, fistulous tract, site of the internal opening and anal tone for assessment of continence.

3. Radiological assessment by MRI and CT scans to confirm the presence and delineate the anatomy of the anal fistulas.

\section{Intraoperative assessment:}

- Site of external opening.

- Site of internal opening.

- Length of the tract.

- Presence of external piles at site of incision.

- Thickness of anal muscles.

\section{Operative procedure:}

All patients underwent LIFT operation (Limura and Giordano, 2015).

The procedure was done under spinal or general anesthesia in lithotomy position.

1. The location of the internal opening was identified by gentle probing of the fistula tract. If probing was unsuccessful, the fistula tract was injected with hydrogen peroxide solution through the external opening. If we could not identify the internal opening by all means, the case was excluded from the study.

2. The inter-sphincteric plane was entered through incision $2-3 \mathrm{~cm}$ at the medial end of the site of fistulous tract.

3. The inter-sphincteric space was identified and entered between internal and external sphincter while the probe 
still in place by dissection using scissors and electrocautery.

4. The inter-sphincteric tract was identified (not cut) and hooked using right-angled clamp.

5. Secure suture ligation or transfixation of inter-sphincteric fistula tract using polyglactin (Vicryl) 3/0 at both sides, one near to the internal opening and the other at the external sphincter defect.

6. The tract was divided in between the points of ligation. Tight suturing of the tract was confirmed by inserting a probe from the external opening or by injection of hydrogen peroxide.

7. The distal part of the tract was thoroughly curetted from the external opening.

8. Approximation of the inter-sphincteric incision wound with Vicryl 3/0 simple interrupted single layer.

\section{Postoperative follow-up:}

- All patients were discharged after 24 hours unless there was complication.

- All patients received oral ciprofloxacin and metronidazole for 7 days.

- Weekly visits during the first month, then every 2 months for the rest of 6 months for assessment of wound healing, presence of postoperative complications specially the Recurrence.

- A successful outcome was defined as the complete healing of the surgical wound and the external opening.

- Persistence of fistula (failure of procedure) was defined as the presence of persistent discharge with no complete wound healing of either the external opening or the intersphincteric wound.

- Recurrence was defined as the reappearance of symptoms after complete healing of the external opening and the inter-sphincteric wound.

\section{Statistical Analysis:}

Data were collected, revised, coded and entered to the Statistical Package for Social Science (IBM SPSS) version 23. The quantitative data were presented as mean, standard deviations and range. Also, qualitative variables were presented as number and percentages. P-value was considered significant when $\mathrm{P}<0.05$. 


\section{RESULTS}

The demographic and characteristics of the studied patients were 18 males and 2 females, seven patents were diabetic, the age ranged from 22-57yrs, BMI ranged from 28-58, with two patients have history of previous fistula operation (Table 1).

Table(1): Demographic and characteristics of the studied patients (20patients)

\begin{tabular}{|c|c|c|}
\hline \multirow{2}{*}{ Sex } & Female & $2(10.0 \%)$ \\
\cline { 2 - 3 } & Male & $18(90.0 \%)$ \\
\hline \multirow{2}{*}{ Age (yrs) } & Mean \pm SD & $38.35 \pm 10.23$ \\
\cline { 2 - 3 } & Range & $22.00-57.00$ \\
\hline \multirow{2}{*}{ BMI } & Mean \pm SD & $38.30 \pm 9.77$ \\
\cline { 2 - 3 } & Range & $28.00-58.00$ \\
\hline \multirow{2}{*}{ DM } & Negative & $13(65.0 \%)$ \\
\cline { 2 - 3 } & Positive & $7(35.0 \%)$ \\
\hline \multirow{2}{*}{ Recurrent fistula } & Negative & $18(90.0 \%)$ \\
\cline { 2 - 3 } & Positive & $2(10.0 \%)$ \\
\hline
\end{tabular}

There was no statistically significant relation found between postoperative complications and sex and age of the studied patients. Also, there was higher incidence of recurrent fistula in patients with postoperative complications than those without postoperative complications but did not reach statistically significant due to lower number of patients with history of recurrent fistula. There was a statistically significant increase in BMI and DM in cases with postoperative complications than those without postoperative complications (Table 2).

Table (2): Relation of postoperative complications with demographic and characteristics of the studied patients

\begin{tabular}{|c|c|c|c|c|c|c|}
\hline & \multicolumn{2}{|c|}{ Post-operative complications } & \multirow{3}{*}{$\begin{array}{c}\text { Test } \\
\text { value }\end{array}$} & \multirow{3}{*}{ P-value } & \multirow{3}{*}{ Sig. } \\
\hline & & Non Complicated & Complicated & & & \\
\hline & & No. $=16$ & No. $=4$ & & & \\
\hline \multirow{2}{*}{ Sex } & Female & $2(12.5 \%)$ & $0(0.0 \%)$ & \multirow{2}{*}{$0.556^{*}$} & \multirow{2}{*}{$>0.05$} & \multirow{2}{*}{ NS } \\
\hline & Male & $14(87.5 \%)$ & $4(100.0 \%)$ & & & \\
\hline \multirow{2}{*}{ Age (yrs) } & Mean \pm SD & $37.13 \pm 10.23$ & $43.25 \pm 9.95$ & \multirow{2}{*}{$-1.076 \bullet$} & \multirow{2}{*}{$>0.05$} & \multirow{2}{*}{$\mathrm{NS}$} \\
\hline & Range & $22-55$ & $35-57$ & & & \\
\hline \multirow{2}{*}{ BMI } & Mean \pm SD & $34.00 \pm 8.20$ & $45.50 \pm 8.79$ & \multirow{2}{*}{$2.478 \bullet$} & \multirow{2}{*}{$<0.05$} & \multirow{2}{*}{ S } \\
\hline & Range & $30-56$ & $28-58<$ & & & \\
\hline \multirow{2}{*}{ DM } & Negative & $13(81.25 \%)$ & $0(0.0 \%)$ & \multirow{2}{*}{$9.286^{*}$} & \multirow{2}{*}{$<0.01$} & \multirow{2}{*}{ HS } \\
\hline & Positive & $3(18.75 \%)$ & $4(100.00 \%)>$ & & & \\
\hline \multirow{2}{*}{ Recurrent fistula } & No & $15(93.80 \%)$ & $3(75.00 \%)$ & \multirow{2}{*}{$1.250^{*}$} & \multirow{2}{*}{$>0.05$} & \multirow{2}{*}{ NS } \\
\hline & Positive & $1(6.30 \%)$ & $1(25.00 \%)$ & & & \\
\hline
\end{tabular}

*:Chi-square test; $\bullet$ : Independent t-test

There was no significant effect of the site of the external and internal opening on the results of the study (Table 3 ). 
EVALUATION OF LIGATION OF INTERSPHINCTERIC FISTULAS...

Table (3): Effect of the site of internal and external opening on the results among the studied patients

\begin{tabular}{|c|c|c|c|c|c|c|}
\hline & & \multicolumn{2}{|c|}{ Post operative complications } & \multirow[b]{2}{*}{$\begin{array}{l}\text { Test } \\
\text { value• }\end{array}$} & \multirow[b]{2}{*}{$\begin{array}{c}P- \\
\text { value }\end{array} \mid$} & \multirow[b]{2}{*}{ Sig. } \\
\hline & & $\begin{array}{c}\text { Non Complicated } \\
\text { No. }=16 \\
\end{array}$ & $\begin{array}{c}\text { Complicated } \\
\text { No. }=4 \\
\end{array}$ & & & \\
\hline \multirow{2}{*}{ Internal opening } & Mean \pm SD & $6.13 \pm 2.5$ & $7.75 \pm 1.5$ & \multirow{2}{*}{-0.992} & \multirow{2}{*}{$>0.05$} & \multirow{2}{*}{ NS } \\
\hline & Range & $1-11$ & $5-11$ & & & \\
\hline \multirow{2}{*}{ External opening } & Mean \pm SD & $6.75 \pm 1.9$ & $7.00 \pm 2.1$ & \multirow{2}{*}{-0.168} & \multirow{2}{*}{$>0.05$} & \multirow{2}{*}{ NS } \\
\hline & Range & $3-11$ & $3-11$ & & & \\
\hline
\end{tabular}

$\bullet:$ Independent t-test

The long of tracks may increase the risk for complications (Table 4).

Table (4): Effect of the length of tracks on the recurrence among the studied patients

\begin{tabular}{|c|c|c|c|c|c|c|}
\hline & \multicolumn{2}{|c|}{ Post-operative complications } & \multirow{3}{*}{ Test value } & \multirow{3}{*}{ P-value } & \\
\hline & & Non Complicated & Complicated & & & Sig. \\
\hline & & No. $=16$ & No. $=4$ & & & \\
\hline $\begin{array}{l}\text { Radiological } \\
\text { assessment }\end{array}$ & Trans-sphincteric & $16(100.00 \%)$ & $4(100.00 \%)$ & - & - & - \\
\hline Ienoth of tract & Mean \pm SD & $7.50 \pm 1.75$ & $10.5 \pm 2.5$ & 2 • & $<005$ & $\mathbf{S}$ \\
\hline Length of tract & Range & $6-13$ & $5-15$ & $2 .{ }^{\bullet}$ & $<0.05$ & $S$ \\
\hline Surgical treatment & LIFT Procedure & $16(100.00 \%)$ & $4(100.00 \%)$ & - & - & - \\
\hline
\end{tabular}

$\because$ Independent t-test

There was no significant effect of the presence of piles with fistula among the studied patient (Table 5).

Table (5): Relation of piles with fistula among the studied patient, and effect of piles on the recurrence

\begin{tabular}{|c|c|c|c|c|c|c|}
\hline & & \multicolumn{2}{|c|}{ Post-operative complications } & \multirow{3}{*}{ Test value* } & \multirow{3}{*}{ P-value } & \multirow{3}{*}{ Sig. } \\
\hline & & Non Complicated & Complicated & & & \\
\hline & & No. $=16$ & No. $=4$ & & & \\
\hline \multirow{2}{*}{ Piles at fistula } & No & $5(31.30 \%)$ & $1(25.00 \%)$ & \multirow{2}{*}{0.060} & \multirow{2}{*}{$>0.05$} & \multirow{2}{*}{ NS } \\
\hline & Positive & $11(68.80 \%)$ & $3(75.00 \%)$ & & & \\
\hline
\end{tabular}

\section{DISCUSSION}

The trans-sphincteric fistula represents about $(25 \%)$ of all fistulas in which the track runs from the inter-sphincteric space, through the external anal sphincter into the ischiorectal space. Further distinction is made between transsphincteric fistulas that traverse the upper two-thirds of the external anal sphincter (high trans-sphincteric fistulas) and trans- sphincteric fistulas that traverse the lower third of the external anal sphincter (low trans-sphincteric fistulas), both types have different management, in which the low type can be treated by fistulectomy while the higher type still needs more easier and effective procedure as LIFT technique (Lunniss and Phillips, 2013).

The present study was a prospective study that was designed to assess the 
short-term term outcome of LIFT procedure in the treatment of 20 patients have trans-sphincteric anal fistula, and the results showed complete healing in $80 \%$ of cases, with a 6 months follow-up of all included patients, recurrence in our patients was reported in $20 \%$ including 1 recurrence and 3 persistence. Findings of the current study were consistent with those of Shanwani and his Colleagues (2010) who conducted a prospective study on 45 patients $17.7 \%$ had recurrence of fistula between 3 and 8 months through median follow-up period of 9 months.

The major complication of peri-anal fistula surgery stills the continence deficiency which makes the main annoyance of most of surgeons. Indeed most of the performed studies did not report major postoperative complications after the LIFT procedure, which confirms the safety of the technique (Shanwani et al., 2010). This was well seen in our study as no patients complained of any changes in their continence. We found that the LIFT procedure is a sphincter-preserving technique with no impairment of continence because the procedure does not cause anal sphincter injury. Also, the use of anal retractors with its deteriorating effect on continence had been avoided.

In the present study, the mean operative time was 36 minutes which coincide with other studies as Sileri et al. (2014) who reported that the operative time ranging between 35 and 40 minutes. This demonstrates that the procedure has a short and reasonable operating time.

The median time for wound healing in our study was 4 weeks. This was nearly equal with that have been reported by Sirikurnpiboon and his Colleagues
(2013). Short wound healing time is one of the advantages of the LIFT technique and can be explained by the presence of small wound in the inter-sphincteric groove which is less liable to contamination.

In this study, the patient's satisfaction after the surgery were achieved in all cured patients $(80 \%)$, and it can be explained by minimal tissue injury associated with the LIFT procedure, resulting in faster recovery, earlier return to work and shorter healing time. Also, anal sphincter injury was avoided. So, continence had not been affected. It has been proven statistically that the quality of our patient's lives has been improved 2 and 4 weeks after the operation. This result of the present study was consistent with Sileri et al. (2014) who studied overall satisfaction 1, 2 and 4 weeks after surgery. They reported that all patients had satisfaction with the results of their treatment.

In the present study, post-operative pain was mild, relative to postoperative pain after other anal operations, and can explain why most studies regarding the LIFT technique did not record the postoperative pain. Univariate analysis revealed five factors associated with statistically significant higher rate of recurrence. These included history of previous surgery for anal fistula, the distance from the anal verge to external opening (length of the track), number of the track(s), high BMI and presence of DM.

We have reported lower success rates in cases with previous history of fistula surgery. This agreed with Abcarian et al. (2012) who reported that healing rates are 
better for patients who have no previous operations (90\% healing rates) versus those who had undergone 1 or more previous operations before undergoing LIFT (70\% healing rate). They believe that this correlation is multifactorial; the possible complexity of the original fistula, manipulation of operative bed, and DE vascularization of native tissues with any subsequent operative intervention may reduce healing rates. They conclude that LIFT is an excellent choice as a first sphincter-sparing procedure for perianal fistula in appropriately selected patients.

Lehmann and Graf (2013) studied the efficacy of LIFT for recurrent anal fistulas. Their study showed that LIFT results in healing of recurrent anal fistula in nearly half of patients with a low morbidity. They concluded that LIFT is a safe procedure for patients with recurrent anal fistula with results comparable with or superior to that of other sphincterpreserving techniques.

As regard the relation between the length of fistula tract and failure of healing after LIFT procedure, Liu and his Colleagues (2013) have found that longer fistula tracts correlate with a lower primary healing rate. They believe that the reason for this observation is that longer tract may potentially be more prone to having persistent epithelial tissue, inflammation, and sepsis, making healing more difficult. So, they concluded that thorough curettage, cauterization, and peroxide irrigation of the external tract at the initial operation and widening of the external opening to facilitate drainage may minimize persistent sepsis and improve healing. This coincided with the results of our study showed that the recurrence increased significantly with the increase of distance between the anal verge and external opening.

Also, number of the tracks and presence of diabetes mellitus was identified as a risk factor for recurrence in our study. This can be explained by being an indicator of the complexity of the fistula. Schulze and Ho (2015) performed LIFT on 75 patients between May 2008 and June 2013. Recurrences were related to fistulas with multiple tracks. There is general consensus that the presence of multiple tracks, diabetes mellitus, perianal collections and long tracks are all associated with a higher chance of failure of LIFT.

As regard, in our study, we found that the high BMI was identified as a risk factor for recurrence and persistence that can be explained by the obesity make the procedure difficult.

We found the reason of failure either recurrence or persistence in our study was due to complex fistula, more than one track (missed tracks), long track as in case which the external opening at 11 O'clock, infected wound due to DM, or release of the knot.

\section{CONCLUSION}

This technique is quite, simple and excellent in long term control of transsphincteric fistula, but actually the corner stone in management of perianal fistula is the accurate diagnosis of the type of fistula, which needs good preoperative imaging by both surgeon and radiologist, followed by good intraoperative assessment of the type of fistula for selection of the appropriate technique of each type. 


\section{REFERENCES}

1. Abcarian AM, Estrada JJ and Park J (2012): Ligation of intersphincteric fistula tract: early results of a pilot study. Diseases of Colon and Rectum, 55(7): 778-782.

2. Baskan O, Koplay M, Sivri M and Erndol C (2014): Our experience with MR imaging of perianal fistulas. Polish journal of Radiology, 79(5): 490-498.

3. De Parades V, Zeitoun JD and Atienza $\mathbf{P}$ (2010): Cryptoglandular anal fistula.Journal of Visceral Surgery, 147(4): e203-e215.

4. Jackson CH, Abbas MA and Haigh PI (2011): Predictors of outcome for anal fistula surgery. Archives of Surgery, 146(9): 10111016.

5. Lehmann JP and Graf W (2013): Efficacy of LIFT for recurrent anal fistula. Colorectal Diseases, 15(5): 592-595.

6. Limura E and Giordano P (2015): Modern management of anal fistula. World Journal of Gastroenterology, 21(1):12-18.

7. Liu WY, Aboulian A and Kaji AH (2013): Long-term results of ligation of intersphincteric fistula tract (LIFT) for fistula-in-ano. Diseases of the Colon and Rectum, 56(3): 343-347.

8. Lunniss PJ and Phillips RK (2013): Anal fistula evaluation and management. Colorectal Surgery E-Book. Companion to Specialist Surgical Practice, 22(1): 212-216.

9. Salati SA and Al Kadi A (2012): Anal cancer-a review. International Journal of Health Sciences, 6(2): 206-209.

10. Schulze B and Ho YH (2015): Management of complex anorectal fistulas with seton drainage plus partial fistulotomy and subsequent ligation of intersphincteric fistula tract (LIFT). Techniques in coloproctology, 19(2): 89-95.

11. Shanwani A, Nor AM and Amri N (2010): Ligation of the intersphincteric fistula tract (LIFT) a sphincter-saving technique for fistula-in-ano. Diseases of the Colon and Rectum, 53(1): 39-42.

12. Sileri P, Giarratano G, Franceschilli L, Limura E, Perrone F, Stazi A and Gaspari AL (2014): Ligation of the intersphincteric fistula tract (LIFT) a minimally invasive procedure for complex anal fistula. Two years results of a prospective multicentric study. Surgical Innovation, 21(5): 476-480.

13. Simpson JA, Banerjea A and Scholefield JH (2012): Management of anal fistula. British Medical Journal, 345(5): e6705e6709.

14. Sirikurnpiboon $S$, Awapittaya $B$ and Jivapaisarnpong $P$ (2013): Ligation of intersphincteric fistula tract and its modification. Results from treatment of complex fistula. World Journal of Gastrointestinal Surgery, 5(4): 123-128.

15. Steele SR, Kumar R, Feingold DL, Rafferty JL and Buie WD (2011): Practice parameters for the management of perianal abscess and fistula-in-ano. Diseases of the Colon and Rectum, 54(12): 1465-1474. 


\section{تقييم ربط الناسور الشرجى بين عضلات الشرج فى علاج الناسور الشرجى الثن عملات}

أبو بكر عبد القادر عطية، محمود محمد أبو اليزيل، نادر محمد عبد الحمبا قسم الجراحة العامة، بكلية الطب، جامعة الأزهر

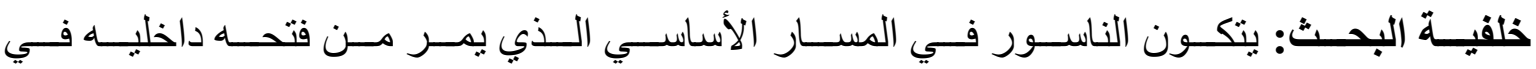

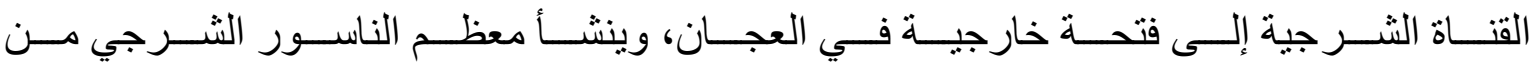

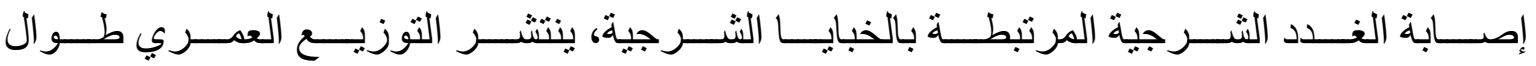

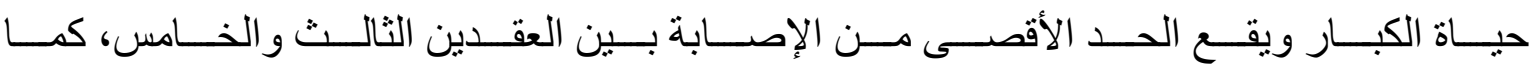

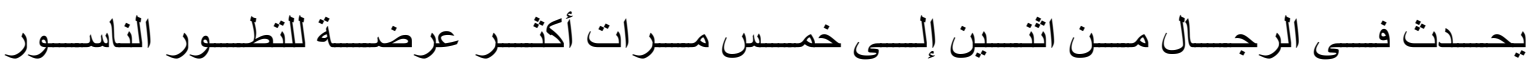
الشرجي من النساء.

الهــدف مــن البحــث: تقيـيم تقنيــة ربــط الناســور الثــرجى بـين عضــلات الثــرج لعـلاج الناسور الشرجي.

المرضـــى وطــرق البحــث: تضــمنت هــذه الدر اســة 20 مريضـــا يعـانون مــن ناســور عبـر

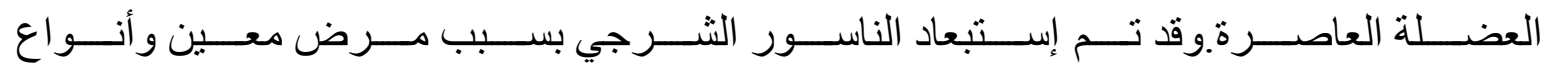

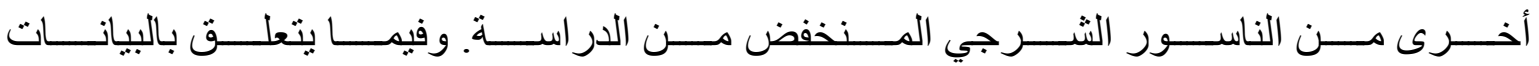

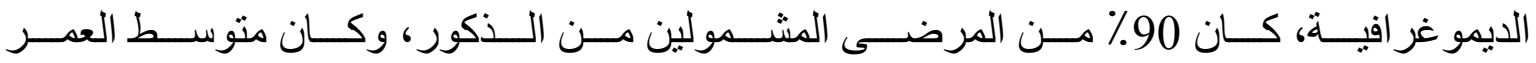

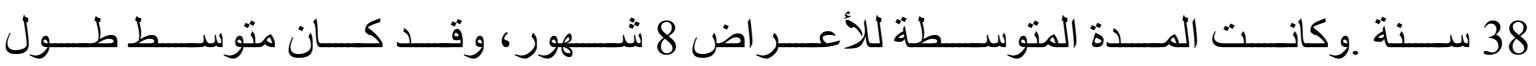

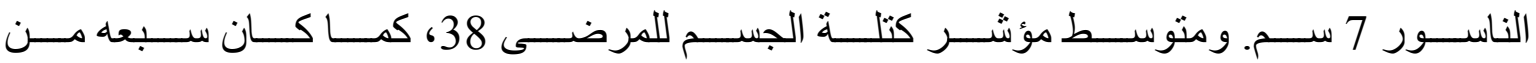

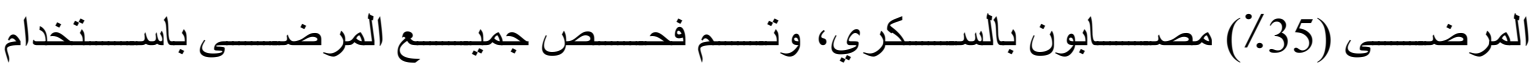
التصوير بالرنين المغناطيسي قبل الجراحة والتصوير المقطعي الثلاثي الأبعاد.

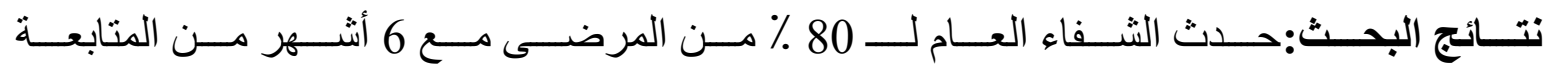

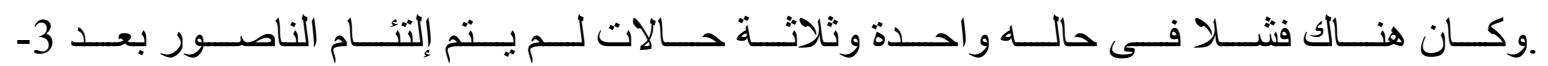

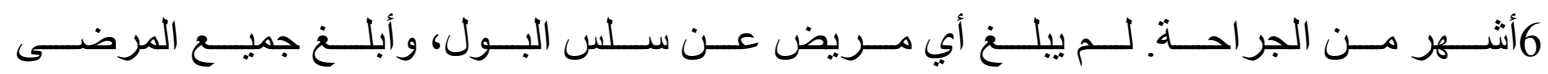
عن السيطرة الطبيعية. وكان متوسط وقت إلتنام الجروح أربعة أسابيع.

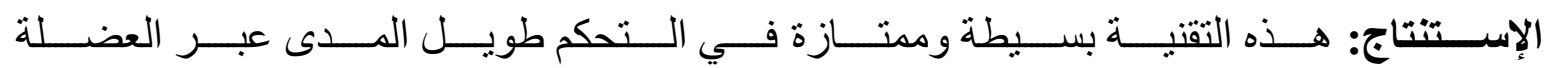

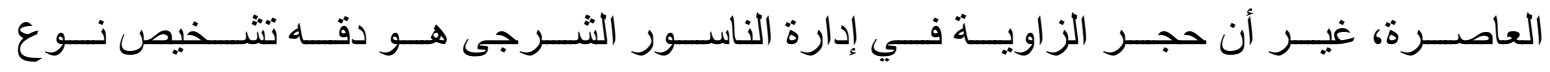




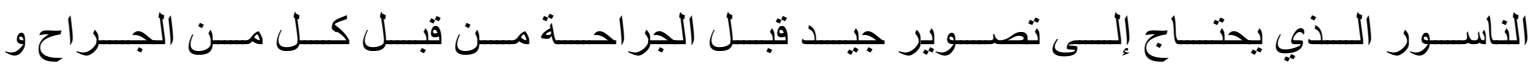

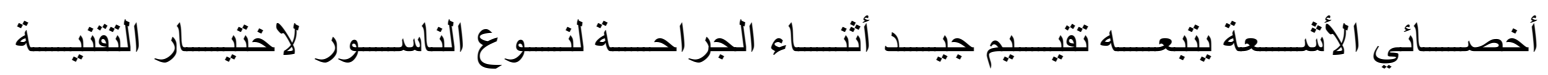
المناسبة لكل نوع. 